\title{
Zdolność upadłościowa i restrukturyzacyjna osoby fizycznej prowadzącej gospodarstwo rolne
}

\author{
Bankruptcy and Legitimacy to Initiate Restructuring Proceedings \\ of a Natural Person Running an Agricultural Holding
}

\section{STRESZCZENIE}

W polskim porządku prawnym aktualnie obowiązują dwa akty prawne składające się na prawo insolwencyjne (tj. zespół rozwiązań i przepisów regulujących sytuację podmiotu niewypłacalnego lub wkrótce niewypłacalnego) - Prawo upadłościowe oraz Prawo restrukturyzacyjne. Osoba fizyczna prowadząca gospodarstwo rolne nie jest $\mathrm{w}$ tych ustawach traktowana jednolicie w zakresie przyznania zdolności do ogłoszenia upadłości oraz legitymacji do wszczęcia postępowania restrukturyzacyjnego. Rolnik jest uważany za przedsiębiorcę w postępowaniu restrukturyzacyjnym i może korzystać z przewidzianych w nim instytucji zmierzających do przywrócenia wypłacalności prowadzonej przez niego działalności. W Prawie upadłościowym pozbawiono go jednak zdolności do ogłoszenia upadłości przewidzianej dla przedsiębiorców, za to przyznano mu możliwość ogłoszenia upadłości przewidzianej dla osób fizycznych nieprowadzących działalności gospodarczej (tzw. upadłości konsumenckiej). Właściwe byłoby włączenie osoby fizycznej prowadzącej gospodarstwo rolne, która jednocześnie legitymuje się statusem przedsiębiorcy w rozumieniu art. $43^{1}$ k.c., do „ogólnego” reżimu postępowania upadłościowego przewidzianego dla przedsiębiorców, co będzie korespondowało z jej statusem w postępowaniu restrukturyzacyjnym.

Słowa kluczowe: upadłość; restrukturyzacja; rolnik; gospodarstwo rolne; przedsiębiorca; przedsiębiorstwo

\section{WSTĘP}

W polskim porządku prawnym aktualnie obowiązują dwa akty prawne składające się na prawo insolwencyjne (tj. zespół rozwiązań i przepisów regulujących sytuację podmiotu niewypłacalnego lub wkrótce niewypłacalnego) ${ }^{1}$ - ustawa $\mathrm{z}$ dnia

1 A. Machowska, M. Geromin, A. Gnys, B. Groele, A. Ludwiczyńska, A. Malmuk-Cieplak, Prawo restrukturyzacyjne i upadłościowe. Zagadnienia praktyczne, Warszawa 2016 (rozdział I). 
28 lutego 2003 r. - Prawo upadłościowe ${ }^{2}$ oraz ustawa z dnia 15 maja 2015 r. - Prawo restrukturyzacyjne ${ }^{3}$. Osoba fizyczna prowadząca gospodarstwo rolne nie jest w tych ustawach traktowana jednolicie w zakresie przyznania zdolności do ogłoszenia upadłości (tzw. zdolności upadłościowej) oraz legitymacji do wszczęcia postępowania restrukturyzacyjnego (tzw. zdolności restrukturyzacyjnej). Rolnik uważany jest za przedsiębiorcę $\mathrm{w}$ postępowaniu restrukturyzacyjnym i może korzystać z przewidzianych $w$ nim instytucji zmierzających do przywrócenia wypłacalności prowadzonej przez niego działalności. W Prawie upadłościowym pozbawiono go jednak zdolności do ogłoszenia upadłości przewidzianej dla przedsiębiorców, za to przyznano mu możliwość ogłoszenia upadłości przewidzianej dla osób fizycznych nieprowadzących działalności gospodarczej (tzw. upadłości konsumenckiej). Celem niniejszego artykułu jest analiza obowiązującego stanu prawnego w tej materii oraz ocena przyjętych rozwiązań.

\section{ZDOLNOŚĆ UPADŁOŚCIOWA OSOBY FIZYCZNEJ PROWADZĄCEJ GOSPODARSTWO ROLNE}

Postępowanie upadłościowe to jedno z postępowań insolwencyjnych występujących w polskim systemie prawnym. W myśl art. 1 ust. 1 ustawa Prawo upadłościowe reguluje: 1) zasady wspólnego dochodzenia roszczeń wierzycieli od niewypłacalnych dłużników będących przedsiębiorcami, 2) zasady dochodzenia roszczeń od niewypłacalnych dłużników będących osobami fizycznymi nieprowadzącymi działalności gospodarczej, 3) skutki ogłoszenia upadłości, 4) zasady umarzania zobowiązań upadłego będącego osobą fizyczną. Przyjęto zasadę, że ogłosić upadłość mogą podmioty, którym przyznano tzw. zdolność upadłościową. Zgodnie $\mathrm{z}$ art. 1 ust. 1 Prawa upadłościowego przepisy tej ustawy stosuje się w stosunku do przedsiębiorców w rozumieniu ustawy z dnia 23 kwietnia 1964 r. - Kodeks cywilny ${ }^{4}$, tj. osób fizycznych, osób prawnych i jednostek organizacyjnych niebędących osobami prawnymi, którym ustawa przyznaje zdolność prawną, prowadzących we własnym imieniu działalność gospodarczą lub zawodową, o ile ustawa nie stanowi inaczej. Podmioty pozbawione zdolności upadłościowej określa art. 6 Prawa upadłościowego. Zgodnie z pkt 5 tego artykułu, nie można ogłosić upadłości osób fizycznych prowadzących gospodarstwo rolne, które nie prowadzą innej działalności gospodarczej lub zawodowej. Upadłość może zatem ogłosić przedsiębiorca będący osobą fizyczną prowadzącą gospodarstwo rolne jedynie wówczas, gdy zajmuje się również inną działalnością gospodarczą lub zawodową. Sama działalność rolnicza

\footnotetext{
2 T.j. Dz.U. z 2016 r., poz. 2171 z późn. zm., dalej jako: Prawo upadłościowe.

3 T.j. Dz.U. z 2017 r., poz. 1508, dalej jako: Prawo restrukturyzacyjne.

4 T.j. Dz.U. z 2017 r., poz. 459 z późn. zm., dalej jako: k.c.
} 
nie pozwala na ogłoszenie upadłości, musi jej towarzyszyć aktywność gospodarcza innego rodzaju, nawet jeżeli ma marginalne znaczenie. W przypadku, gdy dojdzie do ogłoszenia upadłości przez osobę fizyczną prowadzącą gospodarstwo rolne oraz inną działalność gospodarczą lub zawodową, wówczas gospodarstwo rolne wejdzie do masy upadłości ${ }^{5}$ i zostanie przeznaczone na zaspokojenie wierzytelności niezwiązanych z produkcją rolną. Upadłość bez ograniczeń może za to ogłosić osoba prawna, która prowadzi gospodarstwo rolne, nawet gdy nie prowadzi innej działalności gospodarczej ${ }^{6}$.

W uzasadnieniu projektu Prawa upadłościowego brak jest wyraźnego odniesienia do przyczyn wyłączenia osób fizycznych prowadzących gospodarstwo rolne z prawa do ogłoszenia upadłości. Wskazano jedynie, że przyjęto analogiczne rozwiązanie jak we wcześniejszych aktach prawnych regulujących tę materię ${ }^{7}$. Wcześniej, zgodnie z art. 3 § 4 rozporządzenia Prezydenta Rzeczypospolitej z dnia 24 października 1934 r. - Prawo upadłościowe ${ }^{8}$, upadłości nie mogła ogłosić osoba, która nie miała obowiązku wpisania się do rejestru podmiotów prowadzących działalność gospodarczą, a więc także osoba fizyczna prowadząca gospodarstwo rolne ${ }^{9}$. Kryterium decydującym o zdolności upadłościowej były zatem wówczas kryteria formalne, związane z obowiązkiem rejestrowania prowadzenia określonego rodzaju działalności gospodarczej, a nie z rozmiarem czy skalą tej aktywności ${ }^{10}$. Takie rozwiązanie nie było również wynikiem intencjonalnego wyłączenia przez ustawodawcę rolników z możliwości ogłoszenia upadłości, lecz wtórnym odniesieniem do przepisów z zakresu publicznego prawa gospodarczego regulujących obowiązki rejestracyjne przedsiębiorców ${ }^{11}$.

5 S. Gurgul, Prawo upadtościowe. Prawo restrukturyzacyjne. Komentarz, Warszawa 2018, s. 32.

6 Ibidem, s. 32; R. Adamus, [w:] Prawo upadłościowe i naprawcze. Komentarz, red. A. Witosz, Warszawa 2009, s. 36.

7 Uzasadnienie do projektu ustawy Prawo upadłościowe i naprawcze z dnia 29 sierpnia 2002 r., www.sejm.gov.pl [dostęp: 03.01.2018], s. 11.

$8 \quad$ T.j. Dz.U. z 1991 r., nr 118, poz. 512 z późn. zm.

9 Uwagi na temat poprzednich regulacji prawnych: E. Kremer, Odpowiedzialność za zobowiąania związane z prowadzeniem gospodarstwa rolnego, Kraków 2004, s. 285-302; P. Bielski, Zdolność upadłościowa prowadzacego we własnym (wspólnym) imieniu gospodarstwo rolne, „Rejent" 2006, nr 1, s. 52 i n.

10 E. Kremer, op. cit., s. 297.

11 Podobne rozwiązanie (tj. odniesienie do przepisów prawa publicznego regulujących obowiązek rejestracji działalności gospodarczej) przyjęto w projekcie ustawy o zarządzie sukcesyjnym przedsiębiorstwem osoby fizycznej (druk sejmowy nr 2293). W myśl art. 1 projektowanej ustawy reguluje ona zasady tymczasowego zarządzania przedsiębiorstwem po śmierci przedsiębiorcy, który we własnym imieniu wykonywał działalność gospodarczą na podstawie wpisu do Centralnej Ewidencji i Informacji o Działalności Gospodarczej, oraz kontynuowania działalności gospodarczej wykonywanej z wykorzystaniem tego przedsiębiorstwa. Wobec tego, że osoba fizyczna prowadząca gospodarstwo rolne nie podlega wpisowi do CEIDG, zgodnie z wyżej wymienionym projektem, niemożliwe jest zastosowanie instytucji zarządu sukcesyjnego po jej śmierci. 
W literaturze wyrażono pogląd, że omawiany przepis, biorąc pod uwagę względy społeczno-gospodarcze, ma na celu szczególną ochronę osób fizycznych prowadzących gospodarstwo rolne, dla których jest to podstawowe źródło utrzymania ${ }^{12}$. Zdaniem P. Zimmermana: „Intencją ustawodawcy jest chronienie niewielkich gospodarstw rolnych, w sytuacji, kiedy fakt posiadania ziemi uprawnej jest podstawą utrzymania rolnika i jego rodziny" ${ }^{\prime 3}$. Intencja ta nie została jednak wyrażona w art. 6 pkt 5 Prawa upadłościowego - ustawodawca odnosi się do osoby fizycznej prowadzącej gospodarstwo rolne, bez wskazania, jakiego rozmiaru i rodzaju działalność rolniczą ma na myśli. Jak słusznie zaznacza Z. Miczek, na gruncie stanu prawnego, w którym rolnik nie był uprawniony do ogłoszenia upadłości, w tym konsumenckiej, a także do zawarcia układu:

Pozbawienie osób fizycznych, prowadzących gospodarstwo rolne, możliwości ogłoszenia upadłości [...] może być wręcz niekorzystne dla tych osób, gdyż uniemożliwia im możliwość oddłużenia, przy jednoczesnym utrzymaniu w całości gospodarstwa rolnego. [...] Wydaje się, że kolejny raz ustawodawca, kierując sięźle pojętymi interesami określonej grupy społecznej, przyjął rozwiązania prawne, które wbrew pozorom nie będą służyły poprawie jej sytuacji, a wręcz przeciwnie - uniemożliwią sanację gospodarstw rolnych ${ }^{14}$.

Należy zaznaczyć, że pozostałe podmioty wskazane w katalogu zawartym w art. 6 Prawa upadłościowego, wyłączone z możliwości ogłoszenia upadłości (tj. Skarb Państwa, jednostki samorządu terytorialnego, publiczne samodzielne zakłady opieki zdrowotnej, instytucje i osoby prawne utworzone w drodze ustawy, chyba że ustawa ta stanowi inaczej, oraz utworzone w wykonaniu obowiązku nałożonego ustawą), są instytucjami o charakterze publicznym. Głównym celem tych podmiotów jest wykonywanie funkcji państwowych czy prowadzenie działalności o charakterze użyteczności publicznej ${ }^{15}$. Uzasadnieniem wyłączenia możliwości ogłoszenia upadłości tych podmiotów jest konieczność stałego i nieprzerwanego wykonywania przez nich powierzonych zadań, a konsekwencją - obowiązek finansowania ich działalności przez państwo w przypadku niewypłacalności ${ }^{16}$. Podobnie uczelnie oraz fundusze inwestycyjne są specyficznymi podmiotami, o swoistych zadaniach i celach. Brak jest wspólnego mianownika pomiędzy powołanymi podmiotami oraz osobami fizycznymi prowadzącymi gospodarstwa rolne. W zakresie zdolności upadłościowej są jednak traktowane analogicznie.

12 Z. Miczek, Wyłączenia zdolności upadłościowej, „Prawo Spółek” 2005, nr 7-8, s. 76.

${ }_{13}$ P. Zimmerman, Prawo upadłościowe i naprawcze. Komentarz, Warszawa 2015, s. 17.

14 Z. Miczek, op. cit., s. 76.

15 E. Kremer, op. cit., s. 303.

${ }^{16}$ M. Przychodzki, K. Sącińska, Brak zdolności upadłościowej osób prawa publicznego, „Przegląd Prawa Handlowego” 2006, nr 4, s. 27. 


\section{OGŁOSZENIE PRZEZ OSOBĘ FIZYCZNĄ PROWADZĄCĄ GOSPODARSTWO ROLNE UPADŁOŚCI KONSUMENCKIEJ}

Prawo upadłościowe, obok przepisów dedykowanych przedsiębiorcom, przewiduje również regulacje przyznające prawo do ogłoszenia upadłości przez osoby fizyczne nieprowadzące działalności gospodarczej (tzw. upadłość konsumencka). Zgodnie z art. 491 ${ }^{1}$ Prawa upadłościowego przepisy tytułu V, dotyczącego tej materii, stosuje się wobec osób fizycznych, których upadłości nie można ogłosić zgodnie z przepisami działu II tytułu I części pierwszej tej ustawy. W doktrynie wskazuje się, że dopuszczalne jest ogłoszenie upadłości konsumenckiej przez osobę fizyczną prowadzącą gospodarstwo rolne ${ }^{17}$ pomimo tego, że jest to postępowanie przeznaczone dla podmiotów nieprowadzących działalności gospodarczej.

Według przeważającego stanowiska doktryny i orzecznictwa działalność wytwórczą w rolnictwie należy uznać za działalność gospodarczą ${ }^{18} \mathrm{~W}$ rozumieniu ustawy z dnia 2 lipca 2004 r. o swobodzie działalności gospodarczej ${ }^{19}$. Podmiot zajmujący się taką aktywnością ma zaś status przedsiębiorcy w rozumieniu art. $43^{1}$ k.c. (jeżeli spełnia wymogi przewidziane w tym przepisie) ${ }^{20}$. W orzecznictwie wyrażono pogląd, że:

[...] nie ma jednego wzorca określającego w sposób uniwersalny status rolnika jako przedsiębiorcy; zagadnienie to podlega indywidualnemu rozstrzygnięciu przy uwzględnieniu

17 S. Gurgul, op. cit., s. 32; P. Janda, Prawo upadłościowe. Komentarz, Warszawa 2017, komentarz do art. 491 ${ }^{1}$, nb 4; K. Michalak, Ogłoszenie upadłości osób fizycznych nieprowadzących działalności gospodarczej na podstawie znowelizowanej ustawy prawo upadłościowe i naprawcze, „Transformacje Prawa Prywatnego” 2009, nr 3-4, s. 79; W. Głodowski, A. Hrycaj, Zakres podmiotowy i podstawy ogłoszenia , upadłości konsumenckiej”, „Państwo i Prawo” 2010, z. 2, s. 76-77; A.J. Witosz, Prawo upadtościowe. Komentarz, Warszawa 2017, komentarz do art. 491 ${ }^{1}$, nb 2; F. Zedler, Prawo upadłościowe i naprawcze. Komentarz, LEX 2011, komentarz do art. 491 ${ }^{1}$, nb 1. Odmiennie: P. Bodył-Szymala, Rolnik nie może upaść, czyli o dyskryminacji mimo woli, „Rzeczpospolita" 2009, nr 4, s. 16.

${ }^{18}$ R. Budzinowski, Status prawny rolnika jako przedsiębiorcy (zagadnienia wybrane), „Ruch Prawniczy, Ekonomiczny i Socjologiczny” 2002, nr 3, s. 111 i n.; B. Jeżyńska, Producent rolny jako przedsiębiorca, Lublin 2008, s. 100-103; eadem, Przedsiębiorca rolny we wspótczesnym ustroju rolnym, [w:] Kwestia agrarna. Zagadnienia prawne i ekonomiczne, red. P. Litwiniuk, Warszawa 2016, s. 205-215; uchwała NSA w Warszawie z dnia 2 kwietnia 2007 r., II OPS 1/07, LEX nr 249087; wyrok NSA w Warszawie z dnia 29 sierpnia 2007 r., II OSK 1618/06, LEX nr 364703; wyrok SN z dnia 3 października 2014 r., V CSK 630/13, LEX nr 1509115.

19 T.j. Dz.U. z 2017 r., poz. 2168.

${ }^{20}$ R. Budzinowski, op. cit., s. 111 i n.; B. Jeżyńska, Producent rolny...; J.P. Naworski, Status prawny rolnika indywidualnego, „Przegląd Prawa Handlowego” 2012, nr 10, s. 11-19; M. Pietraszewski, Czy rolnik indywidualny jest przedsiębiorca w świetle kodeksu cywilnego?, „Przegląd Prawa Handlowego" 2010, nr 4, s. 48-53; K. Piasecki, Kodeks cywilny. Księga pierwsza. Część ogólna. Komentarz, Warszawa 2003, komentarz do art. 43', nb 2. 
konkretnych okoliczności danego przypadku, pośród których istotne są m.in. zakres prowadzonej działalności rolniczej, jej model oraz stopień organizacyjny ${ }^{21}$.

Nie każdy rolnik ma status przedsiębiorcy, gdyż charakter jego działalności musi spełniać wymogi przewidziane w art. $43^{1}$ k.c. Przedsiębiorcą nie będzie rolnik prowadzący gospodarstwo rolne jedynie na własne potrzeby, nieprodukujący żadnych towarów na zbyt. Nie ma jednak wątpliwości, że większość rolników wytwarzających produkty rolne na rynek ma status przedsiębiorcy.

Jak słusznie zaznacza M. Pietraszewski:

[...] ustawodawca obejmuje rolników indywidualnych pojęciem ,przedsiębiorca”, a jedynie w art. 6 pkt 5 p.u.n. [tj. Prawa upadłościowego - M.K.] odmawia im zdolności upadłościowej. Gdyby bowiem w ogóle nie uznawał rolników indywidualnych za przedsiębiorców, po cóż by wyraźnie wyłączał wobec nich możliwość ogłoszenia upadłości? Brak takiej możliwości wynikałby wtedy z art. 5 ust. 1 p.u.n. w zw. z art. $43^{1}$ k.c. Nie wydaje się natomiast, by art. 6 pkt 5 p.u.n. stanowił zbędne superfluum, jako że kłóciłoby się to z zasadami przyzwoitej legislacji ${ }^{22}$.

Zatem ustawodawca także na gruncie Prawa upadłościowego uznaje osobę fizyczną prowadzącą gospodarstwo rolne za przedsiębiorcę, a jednocześnie dopuszcza ogłoszenie przez taki podmiot upadłości przewidzianej dla podmiotów nieprowadzących działalności gospodarczej z uwagi na zaliczenie go do określonego w art. $491^{1}$ Prawa upadłościowego katalogu osób fizycznych, których upadłości nie można ogłosić zgodnie z przepisami działu II tytułu I części pierwszej Prawa upadłościowego ze względu na wyłączenie przewidziane w art. 6 pkt 5 tej ustawy.

Odmienne są cele postępowania upadłościowego prowadzonego w stosunku do przedsiębiorców oraz osób fizycznych nieprowadzących działalności gospodarczej, co jest zrozumiałe, gdyż tzw. upadłość konsumencka „musi podlegać zasadom odmiennym od reguł dotyczących podmiotów gospodarczych, przede wszystkim zaś musi zostać oparta na całkowicie innej filozofii niż ta, która przyświeca postępowaniom z udziałem wyłącznie przedsiębiorców"23. Zgodnie z art. 2 ust. 1 Prawa upadłościowego postępowanie uregulowane ustawą należy prowadzić tak, aby roszczenia wierzycieli mogły zostać zaspokojone w jak najwyższym stopniu, a jeśli racjonalne względy na to pozwolą - by dotychczasowe przedsiębiorstwo dłużnika zostało zachowane. Przepis ust. 1a tego artykułu uzupełnia, że postępowanie uregulowane ustawą wobec osób fizycznych, o których mowa w art. 5 (tj.

${ }^{21}$ Wyrok SN z dnia 3 października 2014 r., V CSK 630/13.

${ }^{22}$ M. Pietraszewski, op. cit., 52.

${ }^{23}$ A. Machowska, M. Geromin, A. Gnys, B. Groele, A. Ludwiczyńska, A. Malmuk-Cieplak, op. cit. (rozdział I). 
podmiotów, którym przyznano zdolność upadłościową), należy prowadzić również tak, aby rzetelny dłużnik uzyskał możliwość oddłużenia. Odmienne cele określa ust. 3 - postępowanie uregulowane ustawą wobec osób fizycznych nieprowadzących działalności gospodarczej należy prowadzić tak, aby umożliwić umorzenie zobowiązań upadłego niewykonanych w postępowaniu upadłościowym, a jeśli jest to możliwe - zaspokoić roszczenia wierzycieli w jak najwyższym stopniu, przy czym relacja celów upadłości konsumenckiej do celów upadłości przedsiębiorców ma charakter lex specialis - lex generalis ${ }^{24}$. Brak w tym przypadku ukierunkowania na zachowanie przedsiębiorstwa dłużnika ${ }^{25}$, co jest zrozumiałe, ponieważ postępowanie to jest przeznaczone dla osób nieprowadzących działalności gospodarczej. Ma jednak ono zastosowanie do rolników, ale jednocześnie brak jest regulacji, która chroniłaby dalszą działalność gospodarstwa rolnego. Celem postępowania upadłościowego dedykowanego osobom niebędącym przedsiębiorcami jest wykonanie zobowiązań w jego toku oraz umorzenie zobowiązań niewykonanych, a jeżeli to możliwe, zaspokojenie roszczeń wierzycieli w jak najwyższym stopniu. Wszystkie składniki gospodarstwa rolnego dłużnika mogą więc zostać przeznaczone na zaspokojenie wierzycieli wobec braku jakiejkolwiek regulacji dążącej do zachowania gospodarstwa rolnego w całości.

Podkreślić należy, że sytuacja wierzycieli jest odmienna w postępowaniu upadłościowym prowadzonym w stosunku do przedsiębiorcy oraz osoby fizycznej nieprowadzącej działalności gospodarczej. Celem postępowania upadłościowego przedsiębiorcy jest głównie zaspokojenie wierzycieli w jak najwyższym stopniu, natomiast w upadłości konsumenckiej nacisk został położony na umorzenie zobowiązań upadłego, co zmniejsza zakres ochrony interesów wierzycieli.

\section{ZDOLNOŚĆ RESTRUKTURYZACYJNA OSOBY FIZYCZNEJ PROWADZĄCEJ GOSPODARSTWO ROLNE}

Drugim z aktów prawnych składających się na prawo insolwencyjne jest Prawo restrukturyzacyjne, które zgodnie $\mathrm{z}$ art. 1 reguluje: 1) zawieranie przez dłużnika niewypłacalnego lub zagrożonego niewypłacalnością układu z wierzycielami oraz skutki układu, 2) przeprowadzanie działań sanacyjnych. W myśl art. 3 ust. 1 Prawa restrukturyzacyjnego celem postępowania restrukturyzacyjnego jest uniknięcie ogłoszenia upadłości dłużnika przez umożliwienie mu restrukturyzacji w drodze zawarcia układu z wierzycielami, a w przypadku postępowania sanacyjnego - również przez

${ }^{24}$ S. Gurgul, op. cit., s. 11.

${ }^{25}$ „W upadłości »konsumenckiej« pełny walor zachowuje niewątpliwie postulat »zaspokojenia roszczeń wierzycieli w jak najwyższym stopniu« (pozostałe cele mają oczywiście mniejsze znaczenie, a postulat zachowania przedsiębiorstwa dłużnika jest w ogóle bezprzedmiotowy)" (ibidem). 
przeprowadzenie działań sanacyjnych, przy zabezpieczeniu słusznych praw wierzycieli. Przedsiębiorca zyskuje dzięki restrukturyzacji szansę na przywrócenie zdolności do realizowania zobowiązań i powrót do uczestnictwa w obrocie gospodarczym, przy udzieleniu ochrony przed postępowaniami egzekucyjnymi prowadzonymi przez wierzycieli, które mogłyby doprowadzić do pogłębienia trudności finansowych.

Cel postępowania restrukturyzacyjnego jest ściśle powiązany z postępowaniem upadłościowym, ma charakter prewencyjny w stosunku do upadłości. Na gruncie poprzednio obowiązującego stanu prawnego, gdzie postępowanie o analogicznym charakterze jak restrukturyzacja określano jako postępowanie układowe, K. Piasecki zaznaczył, że układ umożliwia wywiązanie się przez dłużnika ze zobowiązań cywilnoprawnych, co w rezultacie zapobiega likwidacji przedsiębiorstwa dłużnika w związku z ogłoszeniem upadłości ${ }^{26}$.

Tzw. zdolność restrukturyzacyjna przysługuje, co do zasady, przedsiębiorcom w rozumieniu art. $43^{1}$ k.c. (art. 1 ust. 1 Prawa restrukturyzacyjnego). Osoba fizyczna prowadząca gospodarstwo rolne ma zdolność restrukturyzacyjną, jeżeli ma zarazem status przedsiębiorcy ${ }^{27}$. W tej ustawie nie przewidziano przy tym analogicznego wyłączenia jak w art. 6 pkt 5 Prawa upadłościowego, brak zatem podstaw do uznania, że rolnik będący przedsiębiorcą nie ma zdolności restrukturyzacyjnej.

Dzięki możliwości udziału w postępowaniu restrukturyzacyjnym osoba fizyczna prowadząca gospodarstwo rolne, przy wsparciu doradcy restrukturyzacyjnego, może przywrócić rentowność prowadzonej działalności rolniczej. Wstrzymanie egzekucji kierowanych do jego majątku oraz zastosowanie środków restrukturyzacyjnych (takich jak m.in. odroczenie terminu zapłaty zadłużenia, rozłożenie spłaty na raty, zmniejszenie wysokości zadłużenia) powoduje, że rolnik ma szansę na odzyskanie wypłacalności i dalsze kontynuowanie produkcji rolnej w gospodarstwie rolnym o lepszej kondycji finansowej. Upadłość i likwidacja działalności gospodarczej według aktualnych poglądów Komisji Europejskiej powinny być ostatecznym rozwiązaniem, gdyż „przedsiębiorca, nawet taki, który przeżywa kryzys ekonomiczny, jest pracodawcą i płatnikiem podatków oraz innych danin publicznoprawnych, zatem istotnym elementem struktury ekonomicznej państwa"28. $\mathrm{Z}$ uwagi na te okoliczności objęcie rolników zakresem zastosowania Prawa re-

${ }^{26}$ K. Piasecki, Prawo upadłościowe. Prawo układowe. Komentarz, Bydgoszcz 1999, s. 354, za: E. Kremer, op. cit., s. 301.

27 S. Gurgul, op. cit., s. 32, 997; A. Hrycaj, Prawo restrukturyzacyjne. Komentarz, Warszawa 2017, komentarz do art. 4, nb 28-29.

${ }^{28}$ Komunikat Komisji z dnia 5 października 2007 r. do Rady, Parlamentu Europejskiego, Europejskiego Komitetu Ekonomiczno-Społecznego i Komitetu Regionów - W jaki sposób przezwyciężyć piętno porażki poniesionej w działalności gospodarczej - działania na rzecz polityki drugiej szansy - Realizacja partnerstwa lizbońskiego na rzecz wzrostu gospodarczego i zatrudnienia, $\operatorname{COM}(2007) 584$ wersja ostateczna, niepublikowany w Dz.Urz., http://eur-lex.europa.eu/legal-content/PL/TXT/?uri=CELEX\%3A52008AE0978 [dostęp: 27.12.2017]. 
strukturyzacyjnego należy ocenić pozytywnie zarówno ze względu na ich własny interes, jak i z uwagi na interes publiczny.

Należy jednak zwrócić uwagę na niekonsekwencję ustawodawcy w systemowym podejściu do niewypłacalności rolników lub zagrożenia jej wystąpieniem. Osoba fizyczna prowadząca gospodarstwo rolne, spełniająca wymogi do przypisania statusu przedsiębiorcy, może prowadzić postępowanie restrukturyzacyjne, dążąc do uniknięcia likwidacji swojego przedsiębiorstwa - gospodarstwa rolnego, ale nie może już ogłosić upadłości, przewidzianej dla przedsiębiorców, wówczas, gdy te działania się nie powiodą. Względem tego podmiotu ma zastosowanie za to postępowanie dotyczące upadłości konsumenckiej, które ma jednak inny cel oraz jest dedykowane podmiotom nieprowadzącym działalności gospodarczej. Widoczny jest więc brak korelacji pomiędzy przepisami dotyczącymi upadłości oraz restrukturyzacji rolnika, pomimo silnego powiązania tych regulacji.

\section{PODSUMOWANIE}

Reasumując rozważania zawarte w opracowaniu, należy zwrócić uwagę na brak spójnego, przemyślanego uregulowania sytuacji osób fizycznych prowadzących gospodarstwo rolne w dwóch aktach prawnych regulujących prawo insolwencyjne. Rolnik traktowany jest odmiennie w Prawie upadłościowym, gdzie uznany jest za osobę niezajmującą się działalnością gospodarczą, oraz w Prawie restrukturyzacyjnym, gdzie korzysta z instytucji dedykowanych przedsiębiorcom celem przywrócenia wypłacalności prowadzonego gospodarstwa rolnego. Brak jest jasnego uzasadnienia takiego rozwiązania.

Właściwe byłoby włączenie osoby fizycznej prowadzącej gospodarstwo rolne, która jednocześnie legitymuje się statusem przedsiębiorcy w rozumieniu art. $43^{1}$ k.c., do „ogólnego" reżimu postępowania upadłościowego przewidzianego dla przedsiębiorców, co będzie korespondowało ze statusem rolnika w postępowaniu restrukturyzacyjnym ${ }^{29}$. Odebranie rolnikowi zdolności upadłościowej uzasadniono jedynie tym, że takie rozwiązanie stanowi powielenie poprzednio obowiązujących przepisów. Znacząco zmieniły się jednak stosunki społeczno-gospodarcze, działalność rolnicza nie różni się od działalności gospodarczej prowadzonej w innych sektorach zarówno pod względem skali, jak i dochodowości ${ }^{30}$. Nie ma uzasadnienia dalszego odmawia-

${ }^{29}$ P. Bielski (op. cit., s. 55 i n.) na gruncie poprzednio obowiązującego stanu prawnego zaproponował również rozwiązanie, zgodnie z którym rolnik - po spełnieniu określonych wymogów, w tym prowadzenia rachunkowości oraz wpisu do właściwego rejestru sądowego - zyskuje zdolność upadłościową.

${ }_{30}$ J. Bieluk, O potrzebie wprowadzenia do prawa polskiego pojęcia przedsiębiorstwa rolnego, „Studia Iuridica Agraria” 2013, t. 11, s. 132. 
nia przyznania rolnikowi statusu przedsiębiorcy w zakresie zdolności upadłościowej przewidzianej dla przedsiębiorców, również z uwagi na interes wierzycieli, którzy są chronieni w większym stopniu w tym postępowaniu niż w procedurach dedykowanych osobom fizycznym nieprowadzącym działalności gospodarczej.

Jako rozwiązanie omawianego problemu można też wskazać wyróżnienie w polskim porządku prawnym pojęcia przedsiębiorstwa rolnego, do którego odpowiednie zastosowanie będą miały przepisy o przedsiębiorstwie i gospodarstwie rolnym $^{31}$. Wówczas regulacje $\mathrm{w}$ zakresie upadłości powinny być zróżnicowane w stosunku do osób prowadzących działalność rolniczą na małą skalę (głównie w celu zaspokojenia własnych potrzeb) oraz przedsiębiorców rolnych, którym winna być przyznana zdolność upadłościowa przewidziana dla innych podmiotów prowadzących działalność gospodarczą. Takie rozwiązanie pozwoli na dostosowanie sytuacji prawnej dużej grupy rolników (dużych przedsiębiorców) do tego, w jaki sposób faktycznie działają, tj. nie inaczej niż przedsiębiorcy w innych sektorach. Jednocześnie nieduże gospodarstwa rolne nadal będą traktowane odpowiednio w stosunku do ich rozmiaru oraz pełnionej roli w gospodarce.

\section{BIBLIOGRAFIA}

Adamus R., [w:] Prawo upadłościowe i naprawcze. Komentarz, red. A. Witosz, Warszawa 2009.

Bielski P., Zdolność upadłościowa prowadzacego we własnym (wspólnym) imieniu gospodarstwo rolne, ,Rejent” 2006, nr 1.

Bieluk J., O potrzebie wprowadzenia do prawa polskiego pojęcia przedsiębiorstwa rolnego, „Studia Iuridica Agraria" 2013, t. 11.

Bodył-Szymala P., Rolnik nie może upaść, czyli o dyskryminacji mimo woli, „Rzeczpospolita” 2009, nr 4.

Budzinowski R., Status prawny rolnika jako przedsiębiorcy (zagadnienia wybrane), „Ruch Prawniczy, Ekonomiczny i Socjologiczny" 2002, nr 3.

Głodowski W., Hrycaj A., Zakres podmiotowy i podstawy ogłoszenia ,upadłości konsumenckiej”, „Państwo i Prawo” 2010, z. 2.

Gurgul S., Prawo upadtościowe. Prawo restrukturyzacyjne. Komentarz, Warszawa 2018.

Hrycaj A., Prawo restrukturyzacyjne. Komentarz, Warszawa 2017.

Janda P., Prawo upadłościowe. Komentarz, Warszawa 2017.

Jeżyńska B., Producent rolny jako przedsiębiorca, Lublin 2008.

Jeżyńska B., Przedsiębiorca rolny we współczesnym ustroju rolnym, [w:] Kwestia agrarna. Zagadnienia prawne i ekonomiczne, red. P. Litwiniuk, Warszawa 2016.

Komunikat Komisji z dnia 5 października 2007 r. do Rady, Parlamentu Europejskiego, Europejskiego Komitetu Ekonomiczno-Społecznego i Komitetu Regionów - W jaki sposób przezwyciężyć piętno porażki poniesionej w działalności gospodarczej - działania na rzecz polityki drugiej szansy - Realizacja partnerstwa lizbońskiego na rzecz wzrostu gospodarczego i zatrudnienia, $\operatorname{COM}(2007) 584$ wersja ostateczna, niepublikowany w Dz.Urz., http://eur-lex.europa.eu/legalcontent/PL/TXT/?uri=CELEX\%3A52008AE0978 [dostęp: 27.12.2017].

${ }^{31}$ Ibidem, s. 144-145. 
Kremer E., Odpowiedzialność za zobowiązania związane z prowadzeniem gospodarstwa rolnego, Kraków 2004.

Machowska A., Geromin M., Gnys A., Groele B., Ludwiczyńska A., Malmuk-Cieplak A., Prawo restrukturyzacyjne i upadłościowe. Zagadnienia praktyczne, Warszawa 2016.

Michalak K., Ogłoszenie upadłości osób fizycznych nieprowadzących działalności gospodarczej na podstawie znowelizowanej ustawy prawo upadłościowe i naprawcze, „Transformacje Prawa Prywatnego" 2009, nr 3-4.

Miczek Z., Wyłączenia zdolności upadłościowej, „Prawo Spółek” 2005, nr 7-8.

Naworski J.P., Status prawny rolnika indywidualnego, „Przegląd Prawa Handlowego” 2012, nr 10.

Piasecki K., Kodeks cywilny. Księga pierwsza. Część ogólna. Komentarz, Warszawa 2003.

Piasecki K., Prawo upadłościowe. Prawo uktadowe. Komentarz, Bydgoszcz 1999.

Pietraszewski M., Czy rolnik indywidualny jest przedsiębiorca w świetle kodeksu cywilnego?, „Przegląd Prawa Handlowego" 2010, nr 4.

Przychodzki M., Sącińska K., Brak zdolności upadłościowej osób prawa publicznego, „Przegląd Prawa Handlowego" 2006, nr 4.

Rozporządzenie Prezydenta Rzeczypospolitej z dnia 24 października 1934 r. - Prawo upadłościowe (t.j. Dz.U. z 1991 r., nr 118, poz. 512 z późn. zm.).

Uchwała NSA w Warszawie z dnia 2 kwietnia 2007 r., II OPS 1/07, LEX nr 249087.

Ustawa z dnia 23 kwietnia 1964 r. - Kodeks cywilny (t.j. Dz.U. z 2017 r., poz. 459 z późn. zm.).

Ustawa z dnia 28 lutego 2003 r. - Prawo upadłościowe (t.j. Dz.U. z 2016 r., poz. 2171 z późn. zm.). Ustawa z dnia 2 lipca 2004 r. o swobodzie działalności gospodarczej (t.j. Dz.U. z 2017 r., poz. 2168). Ustawa z dnia 15 maja 2015 r. - Prawo restrukturyzacyjne (t.j. Dz.U. z 2017 r., poz. 1508).

Uzasadnienie do projektu ustawy Prawo upadłościowe i naprawcze z dnia 29 sierpnia 2002 r., www. sejm.gov.pl [dostęp: 03.01.2018].

Witosz A.J., Prawo upadtościowe. Komentarz, Warszawa 2017.

Wyrok NSA w Warszawie z dnia 29 sierpnia 2007 r., II OSK 1618/06, LEX nr 364703.

Wyrok SN z dnia 3 października 2014 r., V CSK 630/13, LEX nr 1509115.

Zedler F., Prawo upadtościowe i naprawcze. Komentarz, LEX 2011.

Zimmerman P., Prawo upadłościowe i naprawcze. Komentarz, Warszawa 2015.

\section{SUMMARY}

The Polish legal system currently has two legal acts that create insolvent law, which is a set of solutions and provisions regulating the situation of an insolvent (or soon insolvent) entity - the Bankruptcy Law and the Restructuring Law. A natural person running an agricultural holding is not treated equally in these laws in the scope of granting the ability to declare bankruptcy and legitimacy to initiate restructuring proceedings. A farmer is considered to be an entrepreneur in restructuring proceedings and may use the institutions provided in it to restore the solvency of his business. However, in the Bankruptcy Law, he is deprived of the ability to declare bankruptcy provided for entrepreneurs, but he is granted the opportunity to declare bankruptcy foreseen for natural persons not conducting economic activity, so-called consumer bankruptcy. It would be appropriate to include a natural person running an agricultural holding, who at the same time has the status of an entrepreneur within the meaning of art. $43^{1}$ Civil Code, in the "general" bankruptcy regime for entrepreneurs, which will correspond to its status in the restructuring proceedings.

Keywords: bankruptcy; restructuring proceedings; farmer; agricultural holding; entrepreneur; enterprise 